BEYOND DETERRENCE 
Also published by Macmillan in association with the Oxford Research Group

Scilla Elworthy McLean (editor): HOW NUCLEAR WEAPONS DECISIONS ARE MADE

Hugh Miall: NUCLEAR WEAPONS: WHO'S IN CHARGE? Oliver Ramsbotham: MODERNIZING NATO'S NUCLEAR WEAPONS 


\title{
BEYOND DETERRENCE
}

\section{Britain, Germany and the New European Security Debate}

\section{Oliver Ramsbotham}

Research Fellow, School of Peace Studies,

University of Bradford, and Member of the Oxford Research Group

\author{
and
}

\section{Hugh Miall}

Member of the Oxford Research Group

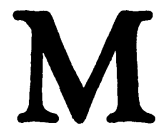

in association with the

PALGRAVE MACMILLAN 


\section{(C) Oxford Research Group 1991}

All rights reserved. No reproduction, copy or transmission of this publication may be made without written permission.

No paragraph of this publication may be reproduced, copied or transmitted save with written permission or in accordance with the provisions of the Copyright, Designs and Patents Act 1988, or under the terms of any licence permitting limited copying issued by the Copyright Licensing Agency, 90 Tottenham Court Road,

London WIP 9HE.

Any person who does any unauthorised act in relation to this publication may be liable to criminal prosecution and civil claims for damages.

First published 1991

\section{Published by}

MACMILLAN ACADEMIC AND PROFESSIONAL LTD

Houndmills, Basingstoke, Hampshire RG21 2XS and London

Companies and representatives

throughout the world

ISBN 978-0-333-56491-2 ISBN 978-1-349-21720-5 (eBook)

DOI 10.1007/978-1-349-21720-5

A catalogue record for this book

is available from the British Library.

Copy-edited and typeset by Povey/Edmondson

Okehampton and Rochdale, England 


\section{Contents}

List of Boxes viii

List of Tables $\quad$ ix

List of Figures $\quad \mathrm{x}$

Acknowledgements $\quad \mathrm{xi}$

Introduction and Summary of Main Argument xii

\section{PART I THE SETTING}

19 NOVEMBER 1989: FIVE ANOMALIES IN THE POST-WAR EUROPEAN SECURITY SYSTEM EXPOSED

1 Continued military confrontation across a politically non-existent frontier

2 A security system dominated by opposing blocs no longer corresponding to political and economic realities

3 The mutual dependence and mutual incompatibility of deterrence and defence in the nuclear age

4 The lavishing of scarce resources on military forces whose main declared function is to prevent their own use

5 The ending of the Cold War to be managed through defence establishments created by it

2 THE NEW AGENDA: WHAT ARE THE BIG QUESTIONS NOW?

1 Where does the threat to security lie? 25

2 What is the appropriate response? 35

3 What should the future security architecture be? 38 
4 What should the role of nuclear weapons be? 45

5 How should resources be spent? 50

6 How should the decisions be made? 53

3 THE TWO POLES OF THE DEBATE 68

1 The realist pole $\quad 72$

2 The transformationist pole 73

3 The nature of the debate $\quad 74$

\section{PART II THE GERMAN DEBATE}

4 GERMAN POLITICS AND THE QUESTION OF SECURITY 1949-89

1 The shadow of the past $\quad 83$

2 The founding of the Federal Republic 87

3 The Christian Democrats and the Westpolitik 1949-66 88

4 The Social Democrats and the Ostpolitik 1969-82 90

5 The emergence of a new agenda 1982-9 92

(a) The Greens (Die Grünen) 94

(b) The Social Democrats (SPD) 95

(c) The Free Democrats (FDP) 97

(d) The Christian Democrats (CDU)/Christian Social Union (CSU)

5 THE NEW GERMAN SECURITY DEBATE 102

1 The threat to security 104

2 The response 107

3 The future security architecture in Europe 109

4 The role of nuclear weapons 111

5 The allocation of resources 113

6 Decision making 114

7 Party political programmes for the December 1990 all-German Federal Elections

(a) The Christian Social Union 114

(b) The Christian Democratic Union 115

(c) The Free Democratic Party 116

(d) The Social Democratic Party 118

(e) The West German Greens, East German Greens/ Bündnis 90, Party of Democratic Socialism (PDS)/Linke Liste 


\section{PART III THE BRITISH DEBATE}

6 THE BRITISH DEFENCE DEBATE IN THE 1980s

1 An insular tradition

2 The Atlanticist consensus 1945-79

3 Labour unilateralism - the electoral albatross

4 Conservative unilateralism - the undetected policy

5 The fate of the centre parties

6 Excluded dissenters

7 The British media and the day the defence debate died

7 1990: THE DEBATE THAT WASN'T 144

1 The Conservative Party 144

2 The Labour Party 147

3 The Liberal Democrats 150

4 The Green Party 151

5 Signs of change 152

8 OUTLINE OF THE NEW BRITISH SECURITY DEBATE

1 The threat to security 156

2 The response 158

3 The future security architecture in Europe 162

4 The role of nuclear weapons 165

5 The allocation of resources 168

6 Decision making 171

7 Summary of questions arising 173

8 Britain, Germany and the future of Europe 177

\section{PART IV CONCLUSION}

9 BEYOND DETERRENCE 189

1 Endings and beginnings 189

2 The age of deterrence and the new security debate 193

3 The central agreement 197

4 Continuing disagreement 199

5 Two asymmetries 202

6 Realist reality: relations of power 202

7 Transformationist reality: the arrow of history 204

Bibliography 223

Index 236 


\section{List of Boxes}

1.1 Flexible response: watershed between deterrence and defence

2.1 Force holdings agreed in the Paris CFE Treaty, 19 November 1990

2.2 NATO nuclear weapons in Europe, 1991

2.3 The tactical air-to-surface missile 47

5.1 All-German elections, $1990 \quad 103$

6.1 Labour Party policy at the time of the 1987 General Election

6.2 Conservative Party policy at the time of the 1987 General Election

6.3 Alliance Party policy at the time of the 1987 General Election

6.4 The radical agenda at the time of the 1987 General Election

8.1 The case of the tactical air-to-surface missile (TASM)

9.1 Relative military strengths of Iraq and the Soviet Union in 1990

9.2 Two hundred years of war and peace in Europe

9.3 Paradoxes of mutual deterrence at strategic level

9.4 Conflict resolution and deterrence

9.5 Nuclear weapons and international law

9.6 Charter of Paris for a new Europe 


\section{List of Tables}

2.1 Membership of European institutions

4.1 Bundestag elections 1949-87

5.1 Fifteen perspectives on a future European security structure 


\section{List of Figures}

1.1 The central front in the 1980s: the greatest concentration of nuclear weapons in the world

1.2 The age of deterrence: strategic and sub-strategic nuclear weapons in Europe in the 1980s

2.1 The fifteen republics of the USSR

2.2 Ethnic and nationalist disputes in Central and Eastern Europe

2.3 Membership of European institutions 1991

4.1 German borders 1937-90

5.1 The sixteen German. Länder 


\section{Acknowledgements}

Hugh Miall and Oliver Ramsbotham are grateful to Betty Booth, Judith Fay, John Hamwee, Rosie Houldsworth, Paul Ingram, Erica Parra, Anne Piper, Tony Thomson and Tony Voss of the Oxford Research Group for support given, including reading and commenting on the text. Scilla Elworthy, Director of the Group, has provided constant inspiration. Jacquie Hope has given invaluable help in translation and advice on German left wing politics. Particular thanks are due to Lothar Gutjahr of the Institut für Friedensforschung und Sicherheitspolitik an der Universität Hamburg for organising the interviews with leading spokespersons from the political parties in the Bundestag on which Chapter 5 is based. His own analysis of West German conservative outlooks on foreign and defence policy between 1986 and 1990 is the finest available study of the subject and we hope to arrange to have it published in Britain as soon as possible. The contribution made by the Media Transcription Service should also be acknowledged.

Additional thanks for comments on passages adapted for an Institute for Public Policy Research paper go to Ken Booth, Michael Clarke, Ronald Higgins, Mary Kaldor, Catherine Kelleher, Patricia Lewis, Robert Neild, Jane Sharp and the Director of the Institute, James Cornford.

The authors are especially grateful to the Barrow and Geraldine S Cadbury Trust, the Network Trust, the Joseph Rowntree Charitable Trust, the Woodstock Trust, the Howard Cheney Peace Settlement and $\mathrm{Dr}$ Hector Cameron who made the work possible. 


\section{Introduction and Summary of Main Argument}

This book begins with the remarkable events of 1989 and 1990. The collapse of communism in Central and Eastern Europe, the Soviet acceptance of the unification of Germany, the signing of the highly asymmetrical Conventional Forces in Europe (CFE) agreement, the announced withdrawal of all Soviet troops based on foreign territory, the unanimous United Nations Security Council condemnation of Iraqi aggression and subsequent endorsement of economic sanctions and military action - these unprecedented developments convinced even hard-headed pragmatists that a critical turning-point in world affairs had now been reached. NATO's London Declaration of 6 July 1990 stated officially that the two alliances 'are no longer adversaries'. The Paris Charter of 21 November 1990 proclaimed 'a new era of peace and cooperation in Europe'. In the wake of the Iraqi invasion of Kuwait the US Secretary of State referred to 'a critical juncture in history', ${ }^{1}$ the British Foreign Secretary to 'a defining moment' in which 'the international community through the United Nations' could create a 'new world order' if the Iraqi challenge to the UN/ CSCE principle of border inviolability was crushed. ${ }^{2}$ In his 1991 new year message to the America people the Soviet President said

'the most important thing now, at this crucial period of history, is firmly to understand that the nations of the world may achieve progress and security for all, and consequently for themselves, only through common efforts, cooperation and acknowledgement of interdependence of interests'. ${ }^{3}$

This amounted to nothing less than a blueprint for a transition from confrontation to cooperation in Europe. The age of great power war had ended in 1945, since when the Cold War era of mutual deterrence associated with superpower domination and the bloc system had 
supervened. As is amplified in the text, this was by its nature a highly ambiguous transitional phase, and, at any rate so far as the 1989 British Statement on the Defence Estimates was concerned, the declared aim now was to move beyond it to create a system of 'mutually assured security' in which:

'the total neutralisation of war becomes so sure, accepted and permanent that, even when interests may differ widely, nations of

East and West can conduct their business together by means in which the thought of armed conflict simply plays no part'. ${ }^{4}$

As 'democracy and the rule of law are extended far and wide', the military dimension would be progressively marginalised, and attention would be concentrated instead on tackling the great common challenges that confronted all CSCE countries, indeed the whole world. For example:

'Our ability to come together to stop or limit damage to the world's environment will be the greatest test of how far we can act as a world community. 5

To this extent by the end of 1990 there can be said at government level to have been an unprecedented measure of declared agreement about ends in Europe. But this needs to be qualified in two ways.

First, in the Soviet Union mounting economic chaos and nationalist separatism have eroded the centre ground that Mikhail Gorbachev has been trying to build on. By the beginning of 1991 the strength of the reactionary backlash has become painfully evident. Unable, or perhaps as a Leninist unwilling, to take the radical path at home, the President seems to be attempting to placate domestic conservative opinion (the crushing of the Baltic Republics and the appointment of Boris Pugo as interior minister) while still preserving the 'new thinking' that has transformed the international scene abroad (continued commitment to the 'common European home' and the appointment of Alexandr Bessmertnykh as foreign minister). It is doubtful if this can be sustained.

Second, in the West, despite the declared agreement about ends, there remains deep and at times bitter disagreement about means. This disagreement covers almost every aspect of the security question and reaches out to embrace the whole of politics. Indeed it involves the definition of security itself. Beneath it lie two poles to the debate, found in various forms in most countries. One is described here as a realist 'view from within', which interprets international affairs as a 
maelstrom of competing state interests and defines threats to security as threats to the interests of particular countries or alliances. From this perspective the emphasis in the West is on collective alliance security and deterrence. The other pole is described as a transformationist 'view from above', which sees the main threats now as common threats throughout the region and the remedies therefore as common remedies. Here the emphasis is on common security and disarmament. The realist view is stronger towards the 'right' end of the political spectrum (or in the Soviet Union among the 'conservatives'), the transformationist view towards the 'left' (or in the Soviet Union among the 'reformers').

What is the significance of this realist/transformationist debate? Its significance lies in the way it relates to the transitional age of mutual deterrence at great power level that Europe is passing through. This era looks both ways - forward to a future age of mutually assured security if war is indeed to be permanently prevented; back to a past age of great power war in case deterrence fails. The realist and transformationist poles recognise different aspects of this hybrid epoch. The realists accurately acknowledge the fact of unregenerate political interests, military capabilities and multiple power centres inherited from the past age of war in Europe. The transformationists recognise the overriding imperatives of mutual vulnerability which now impel all responsible decision-makers forward to a future age of mutually assured security. Neither has a monopoly of the truth. Both must be taken account of in the formulation of policy throughout the continent. But two asymmetries further complicate the situation and give the debate its final significance.

The first asymmetry strongly favours the realist position. It is the fact that, for obvious reasons, realist thinking is entrenched in existing centres of power. This makes realist positions mutually reinforcing. For example, between 1985 and 1990 the extraordinary transformationist initiatives of Soviet Perestroika undermined realist orthodoxy in the West and greatly strengthened transformationist thinking. But the revival of conservative realism in the Soviet Union is likely to have the opposite effect. Realists in the West say that the conservative backlash in the Soviet Union proves how wise they were to insist that the West should keep its guard up. Transformationists say that one contributory reason for this backlash has been the West's inexcusable reluctance to reciprocate Soviet gestures adequately. Whichever view is accepted, it is undoubtedly the case that realists in positions of power are able to appeal to potent particular interests at times of tension, to 
cite rival power centres as justification for their policies, and to manipulate the machinery of state secrecy to stifle opposition and protect themselves from outside challenge. This is becoming increasingly prevalent again in the Soviet Union, where centralised powers of repression are very great, but it is also evident in a different form in the West. Where dissidence is suppressed, in the East or in the West, it is invariably the transformationist voice that is silenced.

The second asymmetry, however, favours the transformationist position. At least, it should do. The logic of mutual vulnerability in the nuclear age now extends to include growing political, economic and cultural interdependence and universal exposure to overarching environmental threats. By determining the penalty of failure, it impels responsible leaders to transcend inherited realist instincts and to embrace the transformationist agenda. In the long term this can only be achieved to the extent that the realist 'view from within' is progressively replaced in centres of power throughout the region by a transformationist 'view from above'. It remains fundamentally important that this should continue to be the case in the Soviet Union, where recent transformationist policies now seem gravely threatened. But for their part Western countries like Britain have so far shown few signs of the necessary imaginative reciprocation, or awareness of the fundamental nature of the transformation that the logic of their own declared long-term policies themselves demand.

In short, both realist and transformationist perspectives play essential roles in the transitional era of mutual deterrence. But, whereas it is the transformationist perspective which eventually needs to prevail, realist instincts throughout the region are still successfully stifling it.

That is why the striking absence of defence/security debate in Britain is to be deplored. The insularity of the British defence debate of the 1980 s as projected through the media, with its emphasis on 'independent' deterrence and 'unilateral' disarmament, was marked. Even this came to an end with the abandonment of unilateralism at the Labour Party conference in October 1989. Since then there has been silence. In 1990 British politics all of a sudden woke up to the fact that the days of 'splendid isolation' were over and the future lay in Europe. In the economic and monetary fields the evolution of Western Europe became a major theme of domestic politics. But the security dimension remained a lacuna. Inherited realist instincts, in the form of nationalist suspicion of European neighbours and Atlanticist yearning for a continuing world role, remained dominant, strongly reinforced by 
the experience of the Gulf war. Questions about the future of Europe, which can only be settled through cooperation with European partners, were drowned out.

This book aims to redress the balance. Despite recent suggestions to the contrary, even from a realist perspective British interests now largely coincide with those of other Western European (and increasingly Central and Eastern European) countries. If attention is focused below the level of national stereotype, a comparable spread of party political opinion can be discerned in most European countries, including Britain. It is a pan-European debate. And it is not so much a case of a simple 'either/or' as of variety of emphasis within a broad overall consensus ranged around the realist and transformationist poles. Unfortunately adversarial two-party British politics obscures this. It gives the impression that there must either be a choice between black-and-white diametric opposites or no debate at all.

Part I outlines the main security questions confronting European decision-makers and describes the two poles to the debate. Part II presents the German debate for purposes of comparison, because, for geographical and historical reasons, the transformationist agenda has been well developed there for many years. Part III analyses the British debate. On the surface it appears as if there have been two different debates going on in Germany and Britain. But closer scrutiny shows that this is not the case. There is now a comparable spread of party political opinion, as is to be expected in two West European democracies which belong to the same alliance (NATO) and community (the EC) and share the same basic interests and concerns. The conclusion to this part of the book (pp. 177-81) is that this should now be explicitly recognised and built on as both countries cooperate in the joint task of shaping a common European future. Part IV returns to the broad theme of Part I and the book ends by stressing the wider significance of the great realist-transformationist debate of which the German and British debates are part.

\section{NOTES}

1. James Baker, testimony to Congress, 5 September 1990.

2. Douglas Hurd, address to the United Nations, 26 September 1990.

3. Mikhail Gorbachev, Soviet News, 2 January 1991, no. 6559. 
4. Statement on the Defence Estimates 1989, vol. 1, HMSO, pp. 11-12.

5. Margaret Thatcher, speech at Aspen, Colorado, 5 August 1990. 